Int. J. Dev. Biol. 48: 451-456 (2004)

\title{
Invasive growth: a genetic program
}

\author{
ALESSANDRA GENTILE* and PAOLO M. COMOGLIO \\ IRCC, Institute for Cancer Research and Treatment, University of Torino School of Medicine, Candiolo, Torino, Italy
}

\begin{abstract}
Invasive growth is defined as a complex biological program which instructs cells to dissociate, migrate, degrade the surrounding matrix, proliferate and survive. Together, these processes account for tissue morphogenesis, homeostasis and repair, and can be aberrantly implemented for cancer dissemination and metastasis. Individual aspects of this process can be controlled by many cytokines and growth factors. However, coordinated regulation of invasive growth as a whole is specifically accomplished by Hepatocyte Growth Factor, a soluble factor which acts through the tyrosine kinase receptor Met. Here we discuss the different biological facets of invasive growth and analyze the intracellular signals which lead to its execution.
\end{abstract}

KEY WORDS: invasive growth, HGF, Met, tyrosine kinase

\section{Introduction}

Tissue plasticity is a fundamental feature of multicellular organisms, which is necessary for the progressive acquisition of a functional identity from undifferentiated cells in embryo development, and for maintenance of the functional integrity of the organism in adult life.

The biological programs that concur in the specification of tissue dynamic changes are orchestrated by a variety of stimuli leading to cell proliferation, survival, and active migration across the extracellular matrix. These events are collectively defined as invasive growth (Comoglio and Trusolino, 2002).

Invasive growth plays a central role in a wide variety of physiological and pathological events. During embryogenesis, it determines events such as gastrulation and nervous system development, and in adult organism regulates inflammatory processes and tissue remodeling during wound healing. The pathological facets are cellular mechanisms that cause local invasion and metastasis. In this scenario, cells proliferate without control, loose contact-inhibition, move from their primitive sites and invade distant tissues, where they survive and grow in an aberrant way and form secondary colonies. Indeed, from both a biological and clinical point of view, a tumour is defined as malignant when neoplastic cells acquire the ability to move from their natural context into the adjacent surroundings and colonize tissues and organs that are distant from the original site of growth (Hanahan and Weinberg, 2000). This process has been carefully documented for epithelial cells, which can be converted into motile and invasive elements by appropriate stimuli (a process known as epithelial-mesenchymal transition, Thiery, 2002). During this process, cells must first disrupt junctions that maintain the organization of the epithelial monolayer, like the tight-junctions and the adherensjunctions, by downregulating junctional proteins. This results in modification of epithelial polarity and in overt cytoskeletal rearrangements. Then, cells must change expression and distribution of their integrin receptors in order to rearrange their connections to the basal membrane and to interact with new molecules of the sub-basal extracellular matrix. In the meantime, increased expression and localized activity of matrix metalloproteinases is instrumental for degrading extracellular matrix components in a polarized way and for facilitating cellular invasion (Fig. 1). Finally, cells that have settled in new territories proliferate and restore the complex interactions with the other cells and with the extracellular matrix in epithelial cells. This last step coincides with cell repolarization and terminal differentiation in tissue patterns that usually resemble branching tubules (Comoglio and Boccaccio, 2001) The program of invasive growth is orchestrated in its specific aspects by a variety of cytokines and growth factors, like epidermal growth factor (EGF), the insulin-like growth factor-1 (IGF-1) and the fibroblast growth factor (FGF). However, the program as a whole is optimally accomplished by a family of soluble growth factors that are known as scatter factors (Cross and Dexter, 1991). The prototype of the scatter factors family is Hepatocyte

\footnotetext{
Abbreviations used in this paper: EGF, Epidermal Growth Factor; FGF, Fibroblast Growth Factor; HCCs, Childhood Hepatocellular Carcinomas; HPRC, Hereditary Papillary Renal Carcinomas; HGF, Hepatocyte Growth Factor; IGF1, Insulin-Like Growth Factor-1; MLP, Mouse Liver Progenitor; OPN, Osteopontin; PI3k PhosphatIdylinositol 3-Kinase; PKB, Protein Kinase B; PLC $\gamma$, phospholipase C $\gamma$.
}

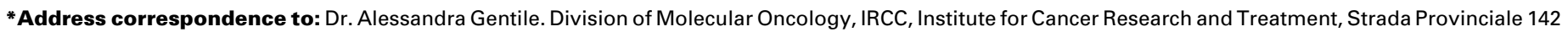
km 3.95, 10060 Candiolo (Torino), Italy. Fax: +39-11-993-3225. e-mail:alessandra.gentile@ircc.it 
Growth Factor (HGF). In this perspective we will discuss the role of HGF in the control and implementation of invasive growth both in its physiological and pathological aspects.

\section{HGF mediates invasive growth}

Hepatocyte Growth Factor (HGF) is a growth factor that elicits multiple cellular responses. In fact, it has been independently identified as a factor that induces dissociation and cell motility in epithelial cells (Scatter Factor, Stoker et al., 1987), and as a mitogen for hepatocytes (HGF, Nakamura et al., 1986). Later, HGF and Scatter Factor were found to be the same molecule (Naldini et al., 1991b). HGF, compared to other growth factors, is a relatively large and complex molecule. It is a heterodimer formed by two chains ( $\alpha$ and $\beta$ ) linked by a disulphide bond. The $\alpha$ chain $(30 \mathrm{kDa})$ shares high homology with enzymes of the blood-clotting cascade and contains the binding site for the receptor. The $\beta$ chain (60 $\mathrm{kDa}$ ) is homologous to serine-proteases, but lacks enzymatic activity. HGF is synthesised and secreted by mesenchymal cells as an inert single chain precursor. Maturation of the precursor into the active $\alpha-\beta$ heterodimer takes place in the extracellular environment and results from the action of different enzymes, such as urokinase-type Plasminogen Activator and a homologue of coagulation factor XII (Naldini et al., 1992).

The receptor for HGF is a transmembrane protein endowed with tyrosine kinase activity encoded by the METprotooncogene (Bottaro et al., 1991) (Naldini et al., 1991b) Met is produced as a single polypeptide chain that during biosynthesis is cleaved into two subunits, an $\alpha$ subunit (50 kDa) and a $\beta$ subunit ( $145 \mathrm{kDa})$, held together by disulfide bonds. The C-terminal of the $\beta$ chain contains an extracellular sequence, a transmembrane domain and a cytoplasmatic protein kinase domain, whereas the $\mathrm{N}$ terminal $\alpha$ chain is completely extracellular.
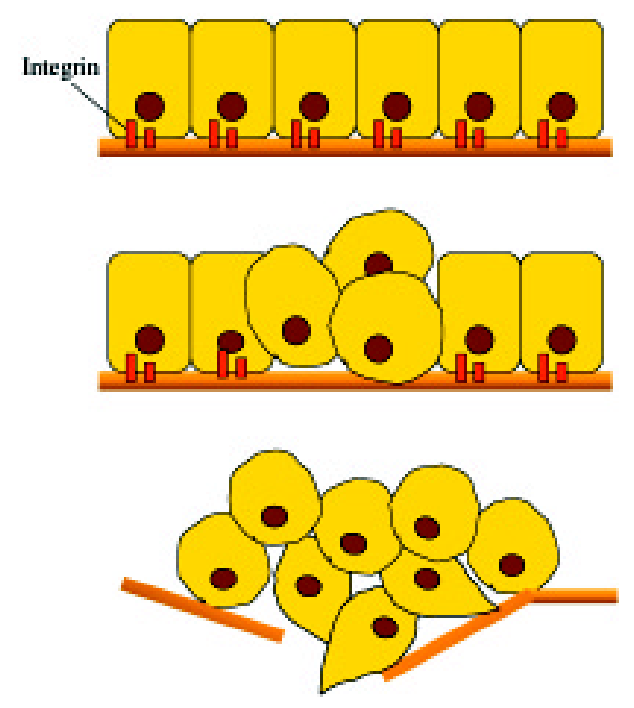

Fig. 1. Steps of epithelial-mesenchymal transition. Epithelial cells proliferate, disrupt cell-cell junctions and reorganize adhesion molecules such as integrins. Finally cells dissolve the basement membrane and invade the stroma underlying the epithelium.
Ligation of HGF to Met results in stimulation of Met kinase activity. In the inactive state, the activation loop of the receptor is in a "closed" conformation, which is inaccessible to substrate and ATP. Upon ligand-induced stabilization of Met-Met dimers, the activation loop is unlocked by trans-autophosphorylation of $\mathrm{Tyr}^{1234}$ and $\mathrm{Tyr}^{1235}$. These two tyrosines represent the major phosphorylation sites of the receptor and are essential for the catalytic activity of the kinase (Naldini et al., 1991a). By contrast, phosphorylation of a juxta-membrane serine residue $\left(\mathrm{Ser}^{985}\right)$ by protein kinase $\mathrm{C}$ or other $\mathrm{Ca}^{(2+)}$-dependent kinase(s) has an inhibitory effect on receptor activity (Gandino et al., 1994).

Once activated, Met elicits intramolecular phosphorylation of two critical tyrosines residues $\left(\mathrm{Tyr}^{1349}\right.$ and $\mathrm{Tyr}^{1356}$ ) located at the $\mathrm{C}$-terminal of the $\beta$ chain. These tyrosine residues, together with the surrounding aminoacids, constitute the so-called multifunctional docking site, a promiscuous motif that, following phosphorylation, mediates interactions with multiple SH2-containing signal transducers, including the cytosolic tyrosine kinase SRC (Ponzetto et al., 1994), the lipid kinase phosphatidylinositol 3kinase (PI3K) (Ponzetto et al., 1994), the transcription factor STAT3 (Boccaccio et al., 1998), and the adaptor proteins GRB2 (Ponzetto et al., 1994), SHC (Pelicci et al., 1995), and GAB1 (Weidner et al., 1996). Gab is a high-capacity scaffolding adaptor that sustains Met indirect interaction with additional transducers, such as phospholipase $\mathrm{C} \gamma(\mathrm{PLC} \gamma)$ and the protein tyrosine phosphatase SHP2 (Maroun et al., 2000) (Fig. 2). By activation of all these pathways, Met receptor triggers a unique biological program that leads to invasive growth. The spectrum of biological events evoked by Met activation comprises proliferation, cell dissociation (scatter), motility, invasion of the surrounding matrix, protection from apoptosis and branching morphogenesis (Fig. 3; Comoglio, 2001).

Whether the specificity of this peculiar response is determined by qualitative activation of specific pathways or by quantitative differences in signaling output is questionable. Evidence for qualitative specificity derives from the possibility to individually dissect Met-dependent signal transduction pathways and to associate each of them to a certain biological response. This strategy has been made possible by pharmacological inhibition of each pathway or by using Met mutants capable of selective activation of the different pathways. The results obtained in vitro indicate that activation of $\mathrm{PI}(3) \mathrm{K}$ alone is sufficient for cell motility (Royal and Park, 1995), the Ras pathway is both necessary and sufficient for proliferation (Ponzetto et al., 1996). STAT activation is necessary for the full biological response (Boccaccio et al., 1998), and activation of PLC- $\gamma$ is required for the differentiation and acquisition of cell polarity (Gual et al., 2000, whereas it is dispensable for cell dissociation, motility and growth. The serine/ threonine kinase c-Akt/protein kinase $B(P K B)$, a downstream effector of $\mathrm{Pl}(3) \mathrm{K}$, is involved in preventing cell anoikis (Zeng et al., 2002). Other reports suggest that specificity of the biological response is also determined by duration of Met signaling, which usually leads to more prolonged activation of downstream transducers compared to other growth factor receptors (Boccaccio et al., 2002; Traverse et al., 1992). Finally, signal specificity may also be contingent on the cellular context in which the receptor works, and on the surface partnerships that Met may contract with other tissue-specific membrane molecules. (for an extensive discussion see Bertotti and Comoglio, 2003). At the moment, it has been 
Fig. 2. HGF and Met. (A) HGF activates the specific receptor Met inducing its dimerization. Once activated, Met recruits multiple adaptors and transducers on its multifunctional docking site. Specific pathways lead to different biological responses which result in invasive growth. (B) HGF is composed of $\alpha$ and $\beta$ chains. The $\alpha$ chain contains four domains known as kringle (K1, K2, $K 3, K 4)$, the signal peptide (SP) and the hairpin loop (HL). The $\beta$ chain contains the serine protease-like structure. (C) HGF signal transduction is mediated by phosphorylation of residues in the multifunctional docking site (Tyr ${ }^{1349}$ and Tyr $\left.^{1356}\right)$ on Met. Met tyrosine kinase activity is positively regulated by the phosphorylation of two tyrosine residues $\left(\right.$ Tyr $^{1234}$ and $T y r^{1235}$ ) and negatively by the phosphorylation of a serine residue $\left(\operatorname{Ser}^{985}\right)$.

demonstrated that Met has at least four partners molecules: Integrin $\alpha 6 \beta 4$ (Trusolino et al., 2001, PlexinB1 (Giordano et al., 2002), CD44 (Orian-Rousseau et al., 2002) and Fas (Wang et al., 2002).

Met is constituvelly associated with Integrin $\alpha 6 \beta 4$ (in carcinoma cells) and its presence on the cell surface is necessary for HGF to exert its characteristic biological effects. $\alpha 6 \beta 4$ is tyrosine-phosphorylated following Met activation and, in turn, recruits Shc and PI3K, thus acting as an additional platform necessary for completion of Met signaling.

Met is also constitutively associated with Plexin B1, a member of the Plexin family that displays some structural similarities with the scatter factor receptors. Stimulation of cells with Sema4D, the ligand of Plexin B1, results in plexin clustering, which in turn drives HGF-independent oligomerization and activation of Met. Sema4D can induce all the biological responses commonly ascribed to HGF; therefore, it can cooperate or even bypass HGF in the induction of invasive growth.

In hepatocellular carcinoma cell lines, Met is constitutively associated with the Fas death receptor, sequestering it and preventing apoptosis triggered by its cognate ligand Fas $\mathrm{L}$.

Finally, Met is associated with CD44. When cells are stimulated with HGF, CD44 interacts with Met and this association is necessary to allow proper Met activation and to assemble a submembraneous network of protein partners, like ezrin, required to efficiently transfer signals from Met to some downstream transducers (MEK and Erk).

In conclusion, we can say that the unique biological responses generated by Met activation are the result of the combination of the integration of individual pathways triggered by receptor activation, the duration and strength of Met signaling, and the protein environment in which the receptor itself is situated.

\section{Met and cancer}

Inappropriate activation of HGF-dependent pathways leads to a malignant process by which tumor cells weaken tissue constraints, migrate, and invade foreign districts, where they give rise to metastases (Birchmeier et al., 1997). Accordingly, Met is

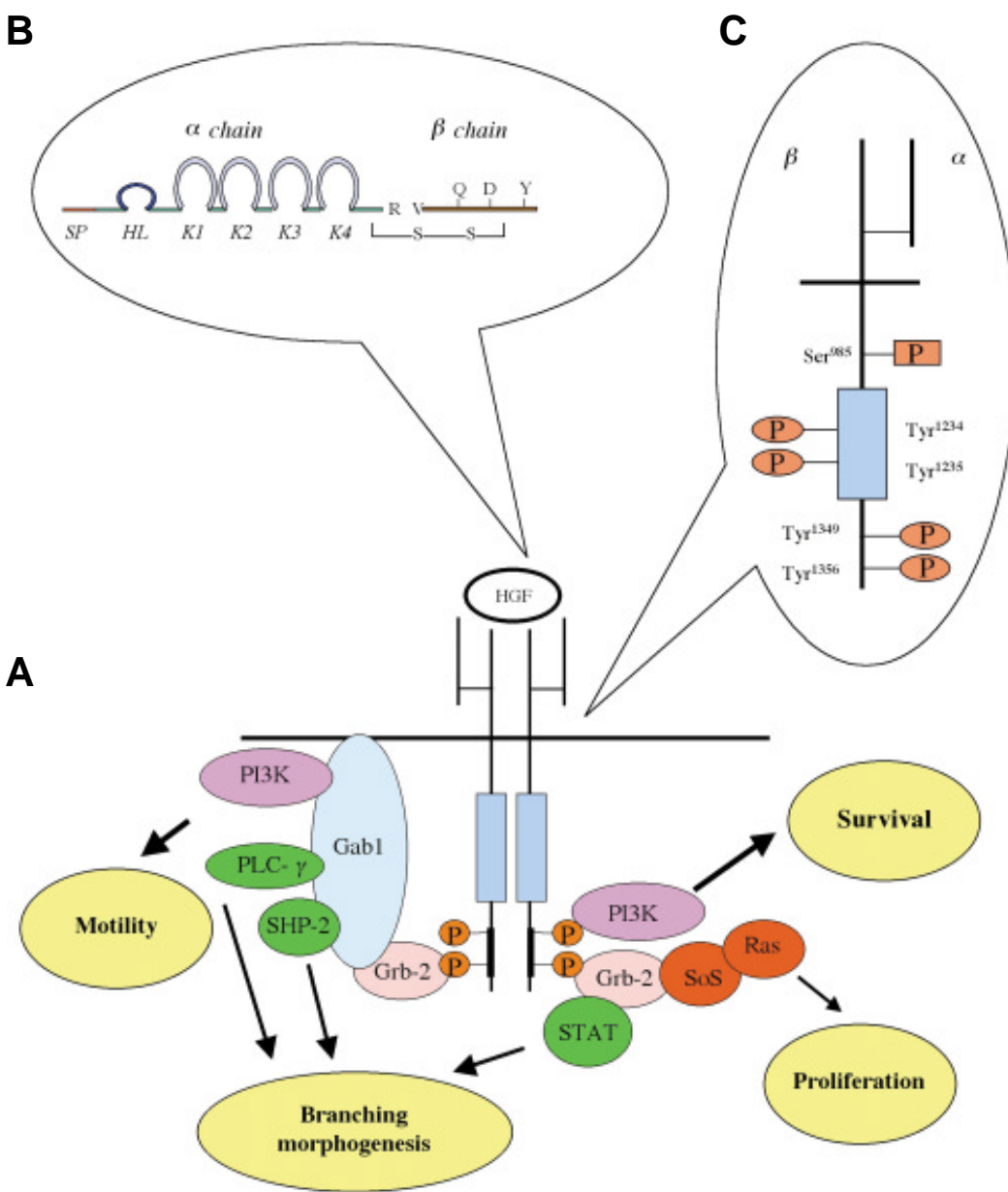

constitutively activated in human cancer by point mutations, overexpression, or autocrine mechanisms. Hereditary and sporadic point mutations have been found in papillary renal carcinomas (HPRC) (Schmidt et al., 1997), somatic mutations in childhood hepatocellular carcinomas (HCCs) (Park et al., 1999), and somatic mutations are selected during the metastatic spread of head and neck squamous-cell carcinomas (Di Renzo etal., 2000). MET overexpression has been observed in tumors of specific histotypes, including thyroid (Di Renzo et al., 1992) and pancreatic carcinomas (Di Renzo et al., 1995b) and correlates with higher metastatic potential. The presence of HGF/Met autocrine loops has been documented in many human rhabdomyosarco-

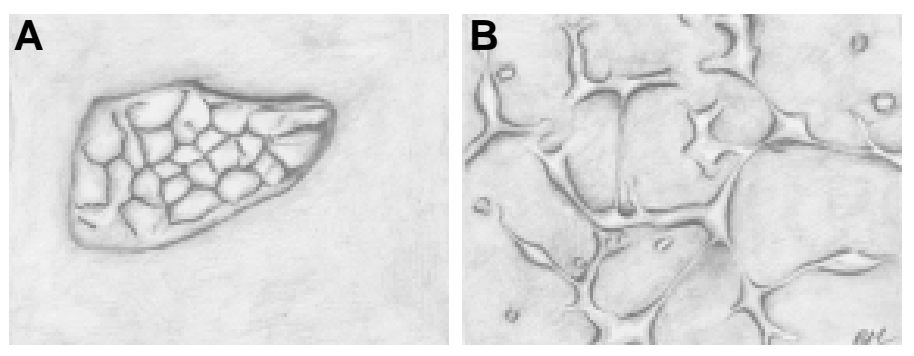

Fig. 3. Graphic representation of cellular scatter induced by HGF stimulation. A colony of hepatic cells is depicted in basal condition (A) and after $48 \mathrm{~h}$ treatment with $\mathrm{HGF}$ (B). 
mas that express Met and secrete HGF, sustaining cell invasiveness and tumor malignancy (Ferracini et al., 1995; Rong and Vande Woude, 1994). Finally, the Met gene is amplified in liver metastases of colorectal carcinomas (Di Renzo et al., 1995a).

\section{Met and development}

In vitro, HGF induces a large variety of biological processes such as motility, migration, protection from apoptosis, angiogenesis, and epithelial branching morphogenesis, which, together, have an obvious in vivo counterpart during development. Experiments of in situhybridization have demonstrated that Met and HGF display a distinct and complementary pattern of expression during mouse embryogenesis, with Met being expressed in epithelial cells of various developing organs, and HGF in nearby mesenchymal cells, suggesting close paracrine ligand-receptor relationships (Sonnenberg et al., 1993).

The crucial developmental role of HGF and Met has been highlighted by the generation of HGF and Met null mutant mouse embryos, which show consistent and superimposable phenotypes. Mice lacking HGF or Met die in utero because of severe defects in placenta development, particularly in trophoblast cells, which impairs the exchange of oxygen and nutrients between the mother and the embryonic bloodstream (Schmidt et al., 1995) (Uehara etal., 1995). In addition, these mutant embryos show liver, muscle and nerve defects. The liver is reduced in size, and shows extensive loss of parenchymal cells. The muscles of the limbs, diaphragm, and tip of the tongue are absent, while the axial skeletal muscles are present, suggesting a role for HGF in the generation skeletal muscles that derive from migratory precursors (Bladt et al., 1995), and in the formation of secondary fibers (Maina et al., 1996). Nerve outgrowth and branching are also compromised independently of the defects in muscle development (Maina et al., 2001).

Similar to what investigated in vitro, the contribution of individual signaling pathways to Met-dependent biological responses has been analyzed also in vivousing mouse knock-in Met mutants able to bind selectively only one particular transducer. The resulting phenotypes have been used as a read-out for the requirement of selected signaling effectors in specific cellular functions (Maina et al., 2001). This kind of approach has demonstrated that signaling through Src is sufficient for placenta development and that PI3K is sufficient to promote outhgrowth of motor axons; conversely, PI3K and Src are not sufficient for Met-mediated hepatocyte survival nor for full migration of myoblast precursors, (Maina et al., 2001). Phenotypic analysis of a Met mutant unable to bind Grb2 has shown that Grb2 is not necessary for the normal development of placenta and liver, whereas it is required for normal development of limb muscles and secondary fibers (Maina et al., 1996).

Collectively, all these data underscore the fundamental role played by Met and HGF during embryonic development and put forward the notion that the signaling requirements for Met function vary depending on the tissue in which they are operative.

\section{A genomic point of view on invasive growth}

A deeper understanding of the molecular bases of epithelial morphogenesis and tumour invasive growth can be achieved by genomic approaches to identify HGF-regulated genes. Indeed, the invasive growth response to HGF requires days for fulfilment and is likely to involve transcriptional regulation of specific target genes. We previously discussed that on activation by HGF, Met concomitantly regulates multiple signal transduction pathways, including Ras, phosphatidylinositol-3-kinase, phospholipase C- $\gamma$, and STAT (Boccaccio et al., 1998;Ponzetto et al., 1994), which in turn have been shown to control the transcriptional status of the cell (Pawson and Saxton, 1999). Furthermore, HGF-stimulated scattering of epithelial cells is ablated by the inhibition of protein neosynthesis (Rosen et al., 1990).

Accordingly, we have recently explored the transcriptional response to HGF in a cell line derived from mouse embryo liver (MLP) (Medico et al., 1996), with two different strategies. Exploiting cDNA microarrays, we have demonstrated that Osteopontin (OPN), a matrix molecule with widespread distribution, (Fet et al., 1989), is a Osteopontin (OPN), major transcriptional target of HGF. We have also shown that HGF, beyond upregulating the OPN level, promotes an autocrine interaction between OPN and its cell surface receptor CD44, which in turn promotes invasiveness. As an alternative approach, we developed a gene trap vector system (Medico et al., 2001). Gene trap vectors are modified retroviral vectors containing a promoterless reporter that is only expressed if the construct integrates downstream an active promoter. By this technique we identified many sequences of genes transcriptionally regulated by HGF, two of them corresponding to known genes, TMP(Ben Porath et al., 1999) and a member of the small prolinerich gene family, SPRR2H(Song et al., 1999).

Another genomic study of the effect of HGF on the transcriptome of the cell has been performed by Ren-qi Yuan et al. They studied by cDNA microarrays the role of HGF in the protection of adriamycin-induced apoptosis in a human cell line of breast cancer (MDA-MB-453). Under these experimental conditions, they found genes upregulated or downregulated by HGF in all functional classes (genes involved in the DNA damage response, cell cycle regulation, signal transduction, protein and RNA synthesis and metabolism, development and cellular differentiation, cellular metabolism, and other functional categories), suggesting that some of the regulated genes are not directly involved in cell survival or apoptotic pathways (Yuan et al., 2001).

Genomic analyses are also a valid tool for clinical approach to invasive growth. Microarrays for mRNA expression profiling have already been used to differentiate primary and metastatic microdissected tumour samples, which has led to the elaboration of a new a molecular classification and characterization of some tumours and to the identification of new markers for diagnosis (Van't Veer etal., 2002) (Ye etal., 2003). It is likely that, In the near future, these genomic analyses will make it possible to identify novel targets for therapeutic intervention.

\section{Acknowledgements}

We are grateful to Livio Trusolino for careful review of the manuscript, and to Enzo Medico and Andrea Rasola for the constructive discussion. We would also to thank Barbara Martinoglio for her graphical support.

\section{References}

BEN PORATH, I., YANUKA, O., and BENVENISTY, N. (1999) The tmp gene, encoding a membrane protein, is a c-Myc target with a tumorigenic activity. Mol Cell Biol 19: 3529-3539.

BERTOTTI, A. and COMOGLIO, P. M. (2003) Tyrosine kinase signal specificity: lessons from the HGF receptor. Trends Biochem Sci28: 527-533. 
BIRCHMEIER, W., BRINKMANN, V., NIEMANN, C., MEINERS, S., DICESARE, S., NAUNDORF, H., and SACHS, M. (1997) Role of HGF/SF and c-Met in morphogenesis and metastasis of epithelial cells. Ciba Found Symp 212: 230-240.

BLADT, F., RIETHMACHER, D., ISENMANN, S., AGUZZI, A., and BIRCHMEIER, C. (1995) Essential role for the c-met receptor in the migration of myogenic precursor cells into the limb bud. Nature 376: 768-771.

BOCCACCIO, C., ANDO', M., and COMOGLIO, P. M. (2002) A differentiation switch for genetically modified hepatocytes. FASEB J16: 120-122.

BOCCACCIO, C., ANDO, M., TAMAGNONE, L., BARDELLI, A., MICHIELI, P., BATTISTINI, C., and COMOGLIO, P. M. (1998) Induction of epithelial tubules by growth factor HGF depends on the STAT pathway. Nature 391: 285-288.

BOTTARO, D. P., RUBIN, J. S., FALETTO, D. L., CHAN, A. M., KMIECIK, T. E., VANDE WOUDE, G. F., and AARONSON, S. A. (1991) Identification of the hepatocyte growth factor receptor as the c-met proto-oncogene product. SCience 251: 802-804.

COMOGLIO, P. M. (2001) Pathway specificity for Met signalling. Nat Ce// Bio/3: E161-E162.

COMOGLIO, P. M. and BOCCACCIO, C. (2001) Scatter factors and invasive growth. Semin Cancer Bio/11: 153-165.

COMOGLIO, P. M. and TRUSOLINO, L. (2002) Invasive growth: from development to metastasis. J Clin Invest 109: 857-862.

CROSS, M. and DEXTER, T. M. (1991) Growth factors in development, transformation, and tumorigenesis. Cel/64: 271-280.

DI RENZO, M.F., OliVERO, M., FERRO, S., PRAT, M., BONGARZONE, I., PILOTTI, S., BELFIORE, A., COSTANTINO, A., VIGNERI, R. and PIEROTTI, M.A. (1992) Overexpression of the c-MET/HGF receptor gene in human thyroid carcinomas. Oncogene 7: 2549-2553.

DI RENZO, M.F., OliVERO, M., GIACOMINI, A., PORTE, H., CHASTRE, E., MIROSSAY, L., NORDLINGER, B., BRETTI, S., BOTTARDI, S., GIORDANO, S., PLEBANI, M., GESPACH, C. and COMOGLIO P.M. (1995) Overexpression and amplification of the met/HGF receptor gene during the progression of colorectal cancer. Clin Cancer Res 1: 147-154.

DI RENZO, M. F., OLIVERO, M., MARTONE, T., MAFFE, A., MAGGIORA, P., STEFANI, A. D., VALENTE, G., GIORDANO, S., CORTESINA, G., and COMOGLIO, P. M. (2000) Somatic mutations of the MET oncogene are selected during metastatic spread of human HNSC carcinomas. Oncogene 19: 1547-1555.

DIRENZO, M. F., POULSOM, R., OLIVERO, M., COMOGLIO, P. M., and LEMOINE, N. R. (1995) Expression of the Met/hepatocyte growth factor receptor in human pancreatic cancer. Cancer Res 55: 1129-1138.

FERRACINI, R., DI RENZO, M. F., SCOTLANDI, K., BALDINI, N., OLIVERO, M., LOLLINI, P., CREMONA, O., CAMPANACCI, M., and COMOGLIO, P. M. (1995) The Met/HGF receptor is over-expressed in human osteosarcomas and is activated by either a paracrine or an autocrine circuit. Oncogene 10: 739-749.

FET, V., DICKINSON, M. E., and HOGAN, B. L. (1989) Localization of the mouse gene for secreted phosphoprotein 1 (Spp-1) (2ar, osteopontin, bone sialoprotein 1, 44-kDa bone phosphoprotein, tumor-secreted phosphoprotein) to chromosome 5, closely linked to Ric (Rickettsia resistance). Genomics 5: 375-377.

GANDINO, L., LONGATI, P., MEDICO, E., PRAT, M., and COMOGLIO, P. M. (1994) Phosphorylation of serine 985 negatively regulates the hepatocyte growth factor receptor kinase. J Biol Chem 269: 1815-1820.

GIORDANO, S., CORSO, S., CONROTTO, P., ARTIGIANI, S., GILESTRO, G., BARBERIS, D., TAMAGNONE, L., and COMOGLIO, P. M. (2002) The semaphorin 4D receptor controls invasive growth by coupling with Met. Nat Cell Bio/4: 720-724.

GUAL, P., GIORDANO, S., WILLIAMS, T. A., ROCCHI, S., VAN OBBERGHEN, E., and COMOGLIO, P. M. (2000) Sustained recruitment of phospholipase Cgamma to Gab1 is required for HGF-induced branching tubulogenesis. Oncogene 19: 1509-1518.

HANAHAN, D. and WEINBERG, R. A. (2000) The hallmarks of cancer. Cel/100:57-70.

MAINA, F., CASAGRANDA, F., AUDERO, E., SIMEONE, A., COMOGLIO, P. M., KLEIN, R., and PONZETTO, C. (1996) Uncoupling of Grb2 from the Met receptor in vivo reveals complex roles in muscle development. Cel/87:531-542.

MAINA, F., PANTE, G., HELMBACHER, F., ANDRES, R., PORTHIN, A., DAVIES, A. M., PONZETTO, C., and KLEIN, R. (2001) Coupling Met to specific pathways results in distinct developmental outcomes. Mol Cel/7: 1293-1306.
MAROUN, C. R., NAUJOKAS, M. A., HOLGADO-MADRUGA, M., WONG, A. J., and PARK, M. (2000) The tyrosine phosphatase SHP-2 is required for sustained activation of extracellular signal-regulated kinase and epithelial morphogenesis downstream from the met receptor tyrosine kinase. Mol Cell Bio/20: 8513-8525.

MEDICO, E., GAMBAROTTA, G., GENTILE, A., COMOGLIO, P. M., and SORIANO, $P$. (2001) A gene trap vector system for identifying transcriptionally responsive genes. Nat Biotechnol19: 579-582.

MEDICO, E., MONGIOVI, A. M., HUFF, J., JELINEK, M. A., FOLLENZI, A., GAUDINO, G., PARSONS, J. T., and COMOGLIO, P. M. (1996) The tyrosine kinase receptors Ron and Sea control "scattering" and morphogenesis of liver progenitor cells in vitro. Mol Biol Cel/7: 495-504.

NAKAMURA, T., TERAMOTO, H., and ICHIHARA, A. (1986) Purification and characterization of a growth factor from rat platelets for mature parenchymal hepatocytes in primary cultures. Proc Natl Acad Sci USA 83: 6489-6493.

NALDINI, L., TAMAGNONE, L., VIGNA, E., SACHS, M., HARTMANN, G., BIRCHMEIER, W., DAIKUHARA, Y., TSUBOUCHI, H., BLASI, F., and COMOGLIO, P. M. (1992) Extracellular proteolytic cleavage by urokinase is required for activation of hepatocyte growth factor/scatter factor. EMBO J11: 4825-4833.

NALDINI, L., VIGNA, E., FERRACINI, R., LONGATI, P., GANDINO, L., PRAT, M., and COMOGLIO, P. M. (1991a) The tyrosine kinase encoded by the MET protooncogene is activated by autophosphorylation. Mol Cel/ Biol11: 1793-1803.

NALDINI, L., WEIDNER, K.M., VIGNA, E., GAUDINO, G., BARDELLI, A., PONZETTO, C., NARSIMHAN, R.P., HARTMANN, G., ZARNEGAR, R. and MICHALOPOULOS, G.K. (1991b) Scatter factor and hepatocyte growth factor are indistinguishable ligands for the MET receptor. EMBO J10: 2867-2878.

ORIAN-ROUSSEAU, V., CHEN, L., SLEEMAN, J. P., HERRLICH, P., and PONTA, $\mathrm{H}$. (2002) CD44 is required for two consecutive steps in HGF/c-Met signaling. Genes Dev 16: 3074-3086.

PARK, W. S., DONG, S. M., KIM, S. Y., NA, E. Y., SHIN, M. S., PI, J. H., KIM, B. J., BAE, J. H., HONG, Y. K., LEE, K. S., LEE, S. H., YOO, N. J., JANG, J. J., PACK, S., ZHUANG, Z., SCHMIDT, L., ZBAR, B., and LEE, J. Y. (1999) Somatic mutations in the kinase domain of the Met/hepatocyte growth factor receptor gene in childhood hepatocellular carcinomas. Cancer Res 59: 307-310.

PAWSON, T. and SAXTON, T. M. (1999) Signaling networks-do all roads lead to the same genes? Cel/97: 675-678.

PELICCI, G., GIORDANO, S., ZHEN, Z., SALCINI, A.E., LANFRANCONE, L., BARDELLI, A., PANAYOTOU, G., WATERFIELD, M.D., PONZETTO, C. and PELICCI, P.G. (1995) The motogenic and mitogenic responses to HGF are amplified by the Shc adaptor protein. Oncogene 10: 1631-1638.

PONZETTO, C., BARDELLI, A., ZHEN, Z., MAINA, F., DALLA, Z. P., GIORDANO, S., GRAZIANI, A., PANAYOTOU, G., and COMOGLIO, P. M. (1994) A multifunctional docking site mediates signaling and transformation by the hepatocyte growth factor/scatter factor receptor family. Cel/77: 261-271.

PONZETTO, C., ZHEN, Z., AUDERO, E., MAINA, F., BARDELLI, A., BASILE, M. L. GIORDANO, S., NARSIMHAN, R., and COMOGLIO, P. (1996) Specific uncoupling of GRB2 from the Met receptor. Differential effects on transformation and motility. J Biol Chem 271: 14119-14123.

RONG, S. and VANDE WOUDE, G. F. (1994) Autocrine mechanism for met protooncogene tumorigenicity. Cold Spring Harb Symp Quant Bio/59: 629-636.

ROSEN, E. M., MEROMSKY, L., GOLDBERG, I., BHARGAVA, M., and SETTER, E. (1990) Studies on the mechanism of scatter factor. Effects of agents that modulate intracellular signal transduction, macromolecule synthesis and cytoskeleton assembly. J Cel/ Sci96 (Pt 4): 639-649.

ROYAL, I. and PARK, M. (1995) Hepatocyte growth factor-induced scatter of MadinDarby canine kidney cells requires phosphatidylinositol 3-kinase. $J$ Biol Chem 270: 27780-27787

SCHMIDT, C., BLADT, F., GOEDECKE, S., BRINKMANN, V., ZSCHIESCHE, W., SHARPE, M., GHERARDI, E., and BIRCHMEIER, C. (1995) Scatter factor/ hepatocyte growth factor is essential for liver development. Nature 373: 699-702.

SCHMIDT, L., DUH, F. M., CHEN, F., KISHIDA, T., GLENN, G., CHOYKE, P., SCHERER, S. W., ZHUANG, Z., LUBENSKY, I., DEAN, M., ALLIKMETS, R., CHIDAMBARAM, A., BERGERHEIM, U. R., FELTIS, J. T., CASADEVALL, C., ZAMARRON, A., BERNUES, M., RICHARD, S., LIPS, C. J., WALTHER, M. M., TSUI, L. C., GEIL, L., ORCUTT, M. L., STACKHOUSE, T., LIPAN J., SLIFE L., BRAUCH H., DECKER J., NIEHANS G., HUGHSON MD., MOCH H., STORKEL S., LERMAN M.I., LINEHAN W.M and ZBAR, B. (1997) Germline and somatic mutations in the tyrosine kinase domain of the MET proto-oncogene in papillary renal carcinomas. Nat Genet 16: 68-73. 
SONG, H. J., POY, G., DARWICHE, N., LICHTI, U., KUROKI, T., STEINERT, P. M., and KARTASOVA, T. (1999) Mouse Sprr2 genes: a clustered family of genes showing differential expression in epithelial tissues. Genomics 55: 28-42.

SONNENBERG, E., MEYER, D., WEIDNER, K. M., and BIRCHMEIER, C. (1993) Scatter factor/hepatocyte growth factor and its receptor, the c-met tyrosine kinase, can mediate a signal exchange between mesenchyme and epithelia during mouse development. J Cell Bio/ 123: 223-235.

STOKER, M., GHERARDI, E., PERRYMAN, M., and GRAY, J. (1987) Scatter factor is a fibroblast-derived modulator of epithelial cell mobility. Nature 327 : 239-242.

THIERY, J. P. (2002) Epithelial-mesenchymal transitions in tumour progression. Nat Rev Cancer 2: 442-454.

TRAVERSE, S., GOMEZ, N., PATERSON, H., MARShALL, C., and COHEN, P. (1992) Sustained activation of the mitogen-activated protein (MAP) kinase cascade may be required for differentiation of $\mathrm{PC} 12$ cells. Comparison of the effects of nerve growth factor and epidermal growth factor. Biochem J288 (Pt 2): 351-355.

TRUSOLINO, L., BERTOTTI, A., and COMOGLIO, P. M. (2001) A signaling adapter function for alpha6beta4 integrin in the control of HGF-dependent invasive growth. Ce//107: 643-654.

UEHARA, Y., MINOWA, O., MORI, C., SHIOTA, K., KUNO, J., NODA, T., and KITAMURA, N. (1995) Placental defect and embryonic lethality in mice lacking hepatocyte growth factor/scatter factor. Nature 373: 702-705.
VAN'T VEER, L. J., DAI, H., VAN DE VIJVER, M. J., HE, Y. D., HART, A. A., MAO, M., PETERSE, H.L., VANDER, K. K., MARTON, M.J., WITTEVEEN, A. T., SCHREIBER, G. J., KERKHOVEN, R. M., ROBERTS, C., LINSLEY, P. S., BERNARDS, R., and FRIEND, S. H. (2002) Gene expression profiling predicts clinical outcome of breast cancer. Nature 415: 530-536.

WANG, X., DEFRANCES, M. C., DAI, Y., PEDIADITAKIS, P., JOHNSON, C., BELL, A., MICHALOPOULOS, G. K., and ZARNEGAR, R. (2002) A mechanism of cell survival: sequestration of Fas by the HGF receptor Met. Mol Cel/9: 411-421.

WEIDNER, K. M., DI CESARE, S., SACHS, M., BRINKMANN, V., BEHRENS, J., and BIRCHMEIER, W. (1996) Interaction between Gab1 and the C-Met receptor tyrosine kinase is responsible for epithelial morphogenesis. Nature 384: 173-176.

YE, Q. H., QIN, L. X., FORGUES, M., HE, P., KIM, J. W., PENG, A. C., SIMON, R., LI, Y., ROBLES, A. I., CHEN, Y., MA, Z. C., WU, Z. Q., YE, S. L., LIU, Y. K., TANG, Z. Y., and WANG, X. W. (2003) Predicting hepatitis B virus-positive metastatic hepatocellular carcinomas using gene expression profiling and supervised machine learning. Nat Med 9: 416-423.

YUAN, R., FAN, S., ACHARY, M., STEWART, D. M., GOLDBERG, I. D., and ROSEN, E. M. (2001) Altered gene expression pattern in cultured human breast cancer cells treated with hepatocyte growth factor/scatter factor in the setting of DNA damage. Cancer Res 61: 8022-8031.

ZENG, Q., CHEN, S., YOU, Z., YANG, F., CAREY, T. E., SAIMS, D., and WANG, C. Y. (2002) Hepatocyte growth factor inhibits anoikis in head and neck squamous cell carcinoma cells by activation of ERK and Akt signaling independent of NFkappa B. J Biol Chem 277: 25203-25208. 